\title{
Dijital pazarlarda Z kuşağının satın alma karar sürecinin incelenmesi*
}

Examining the purchasing decision process of generation $\mathrm{Z}$ in digital markets

Gönderim Tarihi / Received: 04.11.2021

İbrahim YEMEZ ${ }^{1}$

Kabul Tarihi / Accepted: 16.12.2021

Şükran KARACA*2

doi https://doi.org/10.31795/baunsobed.1019171

ÖZ: Son yıllarda teknolojide meydana gelen gelişmelerle birlikte tüketicilerin satın alma davranışlarında değişimler meydana gelmiş ve geleneksel pazarlamadan dijital pazarlamaya doğru bir yönelme söz konusu olmuştur. Özellikle bu durumdan en fazla etkilenen dijital çağda doğmuş olan ve teknolojiye daha bağımlı olan Z kuşağı tüketicileridir. Bu bağlamda çalışmanın amacı, dijital pazarlarda $\mathrm{Z}$ kuşağında yer alan tüketicilerin satın alma karar sürecini incelemektir. Bu amaçla 264 kişiden çevrimiçi anket tekniği ile veriler toplanmıştır. Verilere PLS-SEM ile Faktör Analizi ve Yol Analizi uygulanmıştır. Analiz sonucunda ilk olarak ölçeğin uyum, yakınsak ve ayrışma geçerliliğini sağladığ 1 ve güvenilir bir ölçek olduğu görülmüştür. Yol Analizi sonucunda ise Algılanan Değer, Bilgi Arama, Algılanan Risk, Genel Değerlendirme ve Satın Alma İsteği değişkenlerinin tamamının Tekrar Satın Alma Niyetini yaklaşık olarak \%49 oranında etkilediği bulunmuştur. Ayrıca algılanan değerin bilgi arama ve genel değerlendirme üzerinde, genel değerlendirmenin satın alma isteği üzerinde ve satın alma isteğinin de tekrar satın alma niyeti üzerinde pozitif ve anlamlı bir etkisi vardır.

Anahtar Kelimeler: Dijital pazarlar, Z kuşağı, Satın alma karar süreci, Yol analizi, PLS-SEM

\begin{abstract}
Consumer purchasing behaviour has changed in recent years as a result of technological advancements, and there has been a movement from traditional marketing to digital marketing. In particular, the most affected by this situation are the $\mathrm{Z}$ generation consumers, who were born in the digital age and are more dependent on technology. In this regard, the study's goal is to look into how consumers in the $\mathrm{Z}$ generation make purchase decisions in digital markets. Data was acquired from 264 persons utilizing an online survey technique for this purpose. Factor Analysis and Path Analysis were applied to the data with PLS-SEM. As a result of the analysis, it was seen that the scale provided convergent, convergent and divergent validity and was a reliable scale. As a result of the Path Analysis, it was found that all of the variables Perceived Value, Information Search, Perceived Risk, General Evaluation and Will to Buy affect Repurchase Intent by approximately $49 \%$. Furthermore, perceived value has a positive and substantial impact on information seeking and general evaluation, general evaluation has a positive and significant impact on willingness to buy, and purchase intention has a positive and significant impact on repurchase intention.
\end{abstract}

Keywords: Digital markets, Generation Z, Purchasing decision process, Path analysis, PLS-SEM

\footnotetext{
${ }^{*}$ Bu çalışma, 21.Ulusal / 5.Uluslararası Turizm Kongresi'nde sunulan tam metin bildirinin genişletilmiş halidir.

** Sorumlu Yazar / Corresponding Author

1 Dr. Arş. Gör, Sivas Cumhuriyet Üniversitesi/İ̈B/İşletme/Üretim Yönetimi ve Pazarlama Anabilim Dalı, ibrahimyemez@ cumhuriyet.edu.tr, (1) https://orcid.org/0000-0003-3176-6394

${ }^{2}$ Doç. Dr., Sivas Cumhuriyet Üniversitesi/Turizm Fakültesi/Turizm İşletmeciliği Bölümü/Turizm İşletmeciliği Anabilim Dalı, sukrankaraca@gmail.com, (1) https://orcid.org/0000-0002-0268-1810
} 


\section{EXTENDED ABSTRACT}

\section{Literature review}

The use of the Internet as a source of information and a purchasing platform is fast expanding. The most vulnerable generation is Generation Z. Generation Z (Kutasi, 2013; McCrindle \& Fell, 2019) was primarily influenced by technological advancements; their lives would be unimaginable without smartphones and other digital platforms (Williams and Page, 2011). Generation Z consumers can be referred to as first generation digital natives born with digital chromosomes in their DNA (Kahawandala $\&$ Peter, 2020). The simultaneous consumption of media content is typical of this generation (Pafrey \& Gasser, 2008). These people spend their free time perusing the web, chatting with friends, watching movies, and doing their schoolwork. The lifestyles and reactions to events, experiences and attitudes of those in this generation are somewhat similar. At the same time, they are close to the phenomena in a sociological sense, not biologically (McCrindle, 2014).

Businesses selling products on the Internet need to know the purchasing decision processes of consumers in order to improve their shopping experience and maintain their competitiveness. The biggest challenge for businesses is the $\mathrm{Z}$ generation. Because consumers in this generation have different behaviours and are more focused on innovation (Priporas et al., 2017). Consumer behaviour toward generation $\mathrm{Z}$ needs to be explored, given the rapid rise of this market segment and the importance of its demands and decisions. There are studies examining consumer behaviour in digital markets in domestic and foreign literature (Wu, 2002; Saydan, 2008; Omarl1 \& Par1lt1, 2018). However, this study differs from the existing studies in the literature because of the general evaluation, purchase desire and repurchase intention made in line with the perceived value and perceived risk that emerge as a result of the $\mathrm{Z}$ generation consumers searching for information in digital environments. This research is expected to add to the body of knowledge in this area.

\section{Methodology}

The sample of the study consists of a total of 264 consumers, who were born in 1996 and after, in other words, 17-25 years old, $\mathrm{Z}$ generation, obtained by online survey technique. Data were collected between 20 May-15 June 2021. Data were collected online due to difficulties in data collection, time, cost and limitations such as pandemic. In order for each participant to fill out the questionnaire only once, a login requirement was set and it was also compulsory to fill in all the questions. Therefore, there were no invalid surveys. In the study, a five-point Likert-type consisting of 32 statements was used. The statements in the questionnaire were taken from the studies of Teo and Yeong (2003) and Eeuwen (2017) and translated into Turkish by the researchers. The naming of the factors was also taken from the same study as it was. In addition, there are 5 more expressions in the measurement tool that measure the demographic characteristics of the participants.

\section{Findings and discussion}

First, the SPSS program was utilized in the study, and frequency analysis was employed to show the demographic features of the participants. The data was then analyzed using Factor Analysis and Path Analysis according to the PLS-SEM approach using the SMARTPLS tool.

Factor Analysis with PLS-SEM was used to investigate the concordance, convergent and discriminant validity, and internal consistency of the scale translated into Turkish. Accordingly, the Perceived Value, Information Seeking, Perceived Risk, General Evaluation, Willingness to Purchase, and Repurchase Intention factors in the scale all have CR values greater than 0.7, AVE values greater than 0.5 , and all CR values greater than AVE values. It has been found to provide convergent and convergent validity. Fornell and Lacker criterion coefficients were examined for discriminant validity and it was determined that all factors also provided discriminant validity. Cronbach Alpha coefficients were checked for internal consistency, and it was found that the Information Search and Repurchase Intention factors had values between 0.719 and 0.800 and were quite reliable. Again, Perceived Value, Perceived Risk, General Evaluation and Willingness to Buy factors were found to have scores of 0.805 and above and were found to be highly reliable. 
In the second part of the study, the model was tested with Path Analysis and the validity of the hypotheses was examined by revealing the relations. Accordingly, Perceived Value affects Information Search positively and significantly by approximately $60 \%$, and the $\mathrm{H} 1$ hypothesis was accepted. Again, Perceived Value affects the General Evaluation positively and significantly by approximately $52 \%$, and the $\mathrm{H} 2$ hypothesis was accepted. Studies supporting these findings are available in the literature. Khatibi et al. (2006) and Harn et al. (2006) found that perceived value positively affects information seeking; Teo and Yeong (2003) found in their study that there is a positive relationship between perceived value and general evaluation. Overall Evaluation has a positive and significant effect on Will to Buy and affects approximately $64 \%$. Thus, hypothesis H6 was accepted. Finally, will to buy also has a positive and significant effect on Repurchase Intention, and it affects approximately 70\%. Accordingly, the $\mathrm{H} 7$ hypothesis was also accepted. Cronin et al. (2000) found that perceived value and customer satisfaction had an effect on repurchase intention; Petrick \& Backman (2002) concluded that perceived value and customer satisfaction are determinants of repurchase intention. While the hypotheses H1, H2, H6, H7 were accepted; $\mathrm{H} 3, \mathrm{H} 4$ and $\mathrm{H} 5$ were rejected.

\section{Results and recommendations}

As the number of people using the internet grows, the decision-making mechanisms of consumers are constantly changing. For this reason, businesses that sell over the internet should take these changes into account and adapt their marketing activities accordingly. In addition, there are great developments in worldwide communication due to the intense dissemination of technology and information over the internet through different channels such as smart phones, social media platforms and electronic word of mouth communication. These technological developments have made the world a global village. At the same time, the internet has become ingrained in consumers' daily lives, as they use digital communication channels to seek out product-related information and services. For this reason, the number of studies in different disciplines related to digitalization should be increased more.

The study's most significant limitation is that it is just for $\mathrm{Z}$ generation customers. Second, due to the short time frame and online data collecting, the results gained cannot be applied to the entire population. As a result, it is critical to conduct the research in a longer time period and to include consumers in other generations in order to generalize the results. 


\section{Giriş}

Teknolojik gelişmeler ve akıllı mobil cihazların gelişmesi insanları kullanıcı merkezli, daha ölçülebilir, her yerde bulunan ve etkileşimli yeni bir dijital pazarlama kavramına doğru itmiştir (Pineiro-Otero ve Martínez-Rolán, 2016). Dijital pazarlama, paydaşları sürecin bir parçası olmaya dahil etmek için kişisel bilgisayarlar, akıllı telefonlar, cep telefonları ve oyun konsolları gibi elektronik cihazları kullanan pazarlamadır (Jobber ve Ellis -Chadwick, 2013). Dijital pazarlamada, tüketicilere ulaşmak için dijital kanallar kullanılmaktadır. Böylece dijital kanallar üzerinden yürütülen pazarlama faaliyetleri, pazarlamacıların coğrafi konumlarından bağımsız olarak potansiyel müşterilerle doğrudan iletişim kurmasını sağlamaktadır (Omar ve Atteya, 2020).

Teknolojide meydana gelen gelişmelerle pazarlama ve müşteri ilişkileri gibi alanların yeniden tanımlanmasıyla iş dünyası büyük ölçüde değişmiştir. Bu ortam, elektronik yöntemlerle iş yapma koşullarının kapılarını açmıştır. İnternetin büyümesi, nihayetinde yüz binlerce şirketin çevrimiçi mağazalar kurmasına ve dünya çapında milyonlarca tüketicinin müşterileri haline gelmesini sağlamıştır (Rachinger vd., 2019). Özellikle dijital pazarlama işletmeler tarafından mevcut müşterilerin daha fazla satın almaları veya yeni müşteriler kazanmak için kullanılır (Ponomarenko, 2018). Dijital pazarlar, küresel erişimin çekiciliğine ek olarak, işletmelerin ürün çeşitliliği ve raf alanı tahsisi ile ilgili kararların alınması gereken geleneksel mağazalara kıyasla neredeyse sınırsız raf alanına sahip olmalarına da olanak tanımaktadır. Dijital pazarlardaki büyüme, pazarlamacıların müşterilerini iyi tanımalarını gerekli kılmaktadır (Teo ve Young, 2003). Bu bağlamda daha etkili pazarlama stratejileri tasarlamak ve pazarlama hedeflerine ulaşmak için çevrimiçi alışveriş yapan tüketicilerin karar verme sürecini anlamak önem teşkil etmektedir.

İnternetin bir bilgi kaynağı ve alışveriş platformu olarak erişimi hızla artmaktadır. Buna en duyarlı nesil Z kuşağıdır. 1995 ve 2009 yılları arasında doğan Z Kuşağı (Kutasi, 2013; McCrindle ve Fell, 2019) temelde teknolojik gelişmelerden etkilenmiştir; akıllı telefonlar ve diğer dijital platformlar olmadan hayatları temelde düşünülemez (Williams ve Page, 2011). Z kuşağı tüketicileri, DNA'larında dijital kromozomlarla doğan ilk nesil dijital yerliler olarak ifade edilebilir (Kahawandala ve Peter, 2020). Medya içeriğinin eşzamanlı tüketimi bu neslin tipik bir örneğidir (Palfrey ve Gasser, 2008). Bu bireyler internette gezinirken aynı zamanda arkadaşlarıyla sohbet edip, film izleyip, ödevlerini yaparak vakitlerini geçirirler. Bu kuşaktakilerin yaşam tarzları ve olaylar karşısındaki tepkileri, deneyimleri ve tutumları bir şekilde benzerdir. Ayrıca bunlar fenomenlere biyolojik olarak değil sosyolojik anlamda yakındırlar (McCrindle, 2014).

İnternet üzerinden ürün satan işletmelerin tüketicilerin alışveriş deneyimlerini iyileştirmek ve rekabet gücünü korumak için tüketicilerin satın alma karar süreçlerini bilmeleri gerekmektedir. İşletmeler için en büyük zorluk ise $Z$ kuşağıdır. Çünkü bu kuşakta yer alan tüketiciler farklı davranışlara sahiptir ve yeniliğe daha çok odaklanmışlardır (Priporas vd., 2017). Bu pazar bölümünün hızlı büyümesinin yanı sıra taleplerinin ve kararlarının önemi göz önüne alındığında, $Z$ kuşağına yönelik tüketici davranışının incelenmesi gerekmektedir. Yerli ve yabancı literatürde dijital pazarlarda tüketici davranışlarının incelendiği çalışmalar mevcuttur (Wu, 2002; Saydan, 2008; Omarlı ve Parıltı, 2018). Ancak bu çalışma, literatürdeki mevcut çalışmalardan farklı olarak hem Z kuşağındaki tüketicilere yönelik olması hem de tüketicilerin dijital ortamlardaki genel değerlendirmesinin tekrar satın alma niyetine etkisinin incelenmesinden dolayı farklılaşmaktadır. Çalışmanın bu yönüyle literatüre katkı sağlayacağı düşünülmektedir.

\section{Literatür taraması}

Dijital pazarlarda tüketicilerin satın alma karar sürecinde algılanan değer, bilgi arama ve algılanan risk faktörleri bireylerin genel değerlendirmesi, satın alma isteği ve tekrar satın alma niyeti ile ilişkilidir. $\mathrm{Bu}$ unsurlar ile ilgili bilgilere aşağıda yer verilmiştir.

\section{Algılanan dĕger}

Alıcılar, çevrimiçi olarak sunulan ürünlerin farklı özelliklere sahip olmasından dolayı genellikle hangi web sitesinden satın alacaklarından emin olamazlar. Bu belirsizliği azaltmak için alıcılar bilgi aramaktadırlar. Bilgi arama istekliliği, arama maliyetlerine (zaman, para, arama yapmak için harcanan 
çaba) ve algılanan değere bağlıdır (Marmorstein vd., 1992). Algılanan değer, bir tüketicinin seçim ortamındaki belirsizliği nasıl algıladı̆̆ı, ürünün kendisi için önemi ve riskten kaçınma gibi faktörler tarafından yönlendirilir. Bir kişi bilgi aradığında algıladığı değerin artacağını düşünüyorsa arama yapmaya daha istekli olacaktır çünkü algılanan değer algılanan riskten daha ağır basacaktır. Dijital pazarlarda çevrimiçi bilgi toplama kolaylığı gibi faktörlerin müşterilere daha fazla değer sağlayacağı kabul edilmektedir (Eng ve Kim, 2006). Çevrimiçi satın almadan elde edilen algılanan değer bilgi arama davranışının tetikleyicisidir ve tüketicilerin genel değerlendirmesi de etkilemektedir (Teo ve Young, 2003). E-ticaret ve çevrimiçi perakendecilik alanında yapılan çalışmalar internetin yaygın bilgi erişimi, interaktif deneyim, kolaylık, zaman tasarrufu, çeşitlilik, maliyet tasarrufu ve fiyat karşılaştırması gibi online alışveriş ortamında tüketiciyi olumlu etkileyen çeşitli faydaları olduğunu belirtmişlerdir (Shergill ve Chen, 2005; Khatibi vd., 2006; Harn vd., 2006). Z Kuşağ1 tüketicileri beğendikleri ürünleri bulduklarında genellikle hemen satın almazlar, bunun yerine en iyi firsatları bulmak için bu ürünlerle ilgili diğer web sitelerinde bilgi ararlar (Eszes, 2011). Ürünleri farklı web mağazalarında hızlı ve kolay bir şekilde karşılaştırırlar ve ayrıca satın alma işlemlerini evlerinin rahatllğı̆ıa yönetebilirler (Hidvégi ve Kelemen-Erdős, 2016). Bu bilgiler doğrultusunda aşağıdaki hipotezler oluşturulabilir:

$\mathrm{H}_{1:}$ Algilanan değer bilgi arama üzerinde pozitif etkiye sahiptir.

$\mathrm{H}_{2}$ : Algılanan değer genel değerlendirme üzerinde pozitif etkiye sahiptir.

\section{Bilgi arama}

Bilgi arama, tüketicilerin satın alma kararını vermeden önce edindikleri bilgilerle ilgilidir. Tüketiciler satın alma kararını vermeden önce hem iç hem de dış kaynaklardan bilgi arayabilirler. Bu noktada birincil kaynak, bir müşterinin daha önce deneyimlediği bilgidir. Bu bilgi yeterli değilse müşteri harici bilgi kaynaklarına başvurabilir. Tüketim için ürünün değeri ve önemi temelinde tüketici tarafından ek bir bilgi araştırması yapılabilir. Böyle bir durumda müşteri bilgi arayışını önceki deneyimle sınırlandırılabilir (Oliver vd., 2011). Bilgi kaynakları dijital dünyada müşterilerin parmaklarının ucunda sunulmaktadır (Punj ve Moore, 2009). Müşteriler tarafindan tamamen farklı platformlardan toplanan bilgiler, ihtiyacın uygunluğu açısından değerlendirilir. Müşteriler, satın alma kararlarını vermeden önce çevrimiçi olarak hızlıca kapsamlı bilgi edinebilir. Dünya çapındaki tedarikçilere erişilebilir ve güncel gerçek piyasa fiyatları öğrenilebilir (Palos-Sanchez ve Saura, 2018). Z Kuşağı tüketicileri çevrimiçi alışveriş yaparken ürünlerle ilgili web sitelerini ziyaret ederek fiyatları karşılaştırılabilir, zamandan tasarruf eder ve satın alma deneyimini başkalarıyla paylaşırlar (Hidvégi ve Kelemen-Erdős, 2016). Tüketiciler satın alma kaynaklı algılanan riski azaltmak için bilgiye ihtiyaç duymaktadırlar (Paakkari, 2016). Özellikle belirsizliğin yüksek olduğu, tüketici için daha önemli olan ve fiyatı yüksek ürünlerde bilgiye daha çok ihtiyaç duyulmaktadır. Tüketiciler daha fazla bilgi arayarak belirsizliği azaltacak ve böylece çevrimiçi satın alımlarına ilişkin genel değerlendirme yapmaları kolaylaşacaktır (Teo ve Young, 2003). Goldsmith ve Horowitz (2006), tüketicileri çevrimiçi bilgi aramaya iten faktörlerin risk azaltma, daha düşük maliyet, bilgiye kolay erişim, satın alma öncesi bilgi edinme ve algılama gibi unsurlar olduğunu belirtmişlerdir. Chaturvedi vd. (2016) tarafindan yapılan çalışmada ise, çevrimiçi alışverişten algılanan risk ile çevrimiçi bilgi arama arasında ilişki olduğu sonucuna ulaşmışlardır. Bu doğrultuda şu hipotezler oluşturulabilir:

$\mathrm{H}_{3}$ : Bilgi arama algilanan risk üzerinde pozitif etkiye sahiptir.

$\mathrm{H}_{4}$ : Bilgi arama genel değerlendirme üzerinde pozitif etkiye sahiptir.

\section{Algılanan risk}

Çevrimiçi satın almanın önündeki en önemli engellerden biri, algılanan risktir. Algılanan risk, tüketicilerin kararlarının sonuçlarından emin olamadıklarında kabul etmek zorunda oldukları belirsizlik anlamına gelmektedir (Paakkari, 2016). Çevrimiçi alışveriş geleneksel alışverişe kıyasla daha riski olarak algılandığından (Mohseni ve Sreenivasan, 2014), müşteriler genellikle bir çevrimiçi işlem için karar vermeleri gerektiğinde isteksizdir (Mandilasa vd., 2013). Dolayısıyla tüketiciler satın almayı düşündükleri ürünle ilgili algıladıkları riskin yüksek olması durumunda ürünü satın almamaya karar verebilirler. Bu bilgiler ışığında şu hipotez oluşturulabilir:

$\mathrm{H}_{5}$ : Algılanan risk genel değerlendirme üzerinde negatif etkiye sahiptir. 


\section{Genel değerlendirme, satın alma isteği ve tekrar satın alma niyeti}

Genel değerlendirme, satın alınması düşünülen ürünlerle ilgili algılanan olumlu ya da olumsuz fikirlerdir. Çevrimiçi satın alma sürecinde genel değerlendirme yapılırken algılanan kalite, ürün özellikleri ve arzu edilirlik gibi çeşitli faktörler incelenebilir. Aynı zamanda çevrimiçi alışverişin yüksek derecede konumdan bağımsız erişilebilirlik sunması, satın alma kolaylığı ve esnekliğin en üst düzeye çıkması (Suki ve Suki, 2007) gibi faktörlerde dikkate alınabilir. Tüm bu faktörler, tüketicinin yaptığı genel değerlendirmenin bir parçasıdır (Teo ve Young, 2003).

Satın alma isteği ise, tüketicinin ürünü satın alma niyetinde olma olasılığı olarak tanımlanır (Teo ve Young, 2003). Tüketiciler satın almayı düşündükleri ürünlerle ilgili bilgi arayarak algılanan değer ve algılanan riski değerlendirerek ürün satın alıp almamaya karar verirler. Wood ve Scheer (1996), algılanan riskin satın alma isteğini etkilediği; Agarwal ve Teas (2002) ise algılanan değerin satın alma isteğini pozitif yönde etkilediğini ifade etmişlerdir. Tüketici bu incelemeler sonucunda satın almayı düşündüğü ürünlerle ilgili bir genel değerlendirme yapar. Daha sonra da yapılan bu genel değerlendirme tüketicilerin satın alma isteğini oluşturur. Satın alma sonucu ihtiyaçlar karşılanmışsa veya sorun çözülmüşse, müşterinin ürünü başkalarına önerme ve tekrar aynı ürünü satın alma ihtimali yüksektir (Omar ve Atteya, 2020). Bu bilgiler ışığında şu hipotezler oluşturulabilir:

$\mathrm{H}_{6}$ : Genel değerlendirme satın alma isteği üzerinde pozitif etkiye sahiptir.

$\mathrm{H}_{7}$ : Satın alma isteği tekrar satın alma niyeti üzerinde pozitif etkiye sahiptir.

\section{Araştırmanın metodolojisi}

Araştırmanin örneklemi

Çalışmanın evrenini Türkiye'de yaşayan Z kuşağından tüketiciler oluşturmaktadır. Çalışmanın örneklemini ise 1996 yılı ve sonrasında doğan başka bir ifadeyle 17-25 yaşında, Z kuşağından olan, online alışveriş yapan, çevrimiçi anket tekniği ile elde edilmiş toplam 264 tüketici oluşturmaktadır. Anket sosyal medya ve mobil uygulamalar ile paylaşılarak katılımcılardan doldurmaları istenmiştir. Veriler 20 Mayıs-15 Haziran 2021 tarihleri arasında toplanmıştır. Veri toplamada yaşanan zorluklar, zaman, maliyet ve pandemi gibi kısıtlar nedeniyle veriler çevrimiçi olarak toplanmıştır. Anketi her katılımcının sadece bir kere doldurabilmesi için oturum açma şartı konulmuş ve tüm soruların doldurulması da yine zorunlu tutulmuştur. Dolayısıyla geçersiz anket olmamıştır.

Çalışma için Sivas Cumhuriyet Üniversitesi Sosyal Bilimler Etik Kurulu tarafindan 07/06/2021 tarih ve 050.06.04-45675 sayılı etik kurul onayı alınmıştır.

\section{Veri toplama aract}

Çalışmada beşli Likert tipinde toplam 32 adet ifadeden oluşan bir ölçek kullanılmıştır. Ankette yer alan ifadeler Teo ve Yeong (2003) ve Eeuwen (2017)'in çalışmalarından alınmış ve araştırmacılar tarafından Türkçeye çevrilmiştir. Yine faktörlerin adlandırılması da aynı çalışmadan olduğu gibi alınmıştır. Ayrıca ölçüm aracında katılımcıların demografik özelliklerini ölçen toplam 5 adet ifade daha vardır. Anket ifadeleri aşağıdaki gibidir:

\section{Bilgi arama}

Çevrimiçi satın almaya karar vermeden önce çok fazla zaman harcarım.

Çevrimiçi ürünler hakkında bilgi almak için web sitelerinde çok zaman harcarım.

Çevrimiçi ürün satın almadan önce çok sayıda web sitesini ziyaret ederim.

\section{Algılanan dĕger}

Çevrimiçi satın almadan önce internette arama yaparım.

Web sitelerinde daha fazla bilgi arayarak en iyi satın almayı yapacağımdan eminim.

Hangi ürünlerin benim için uygun olduğunu internette araştırarak öğrendim.

Çeşitli sitelerde arama yapmak, çevrimiçi satın alırken en düşük fiyatı bulmama yardımcı olur.

Çevrimiçi satın almadan önce yeterince arama yaparak tam istediğimi ürünü alırım. 
Çevrimiçi ürün satın almam gerektiğinde ürünler hakkında bilgili değilsem kaybedecek çok şey var demektir.

Aceleyle bir çevrimiçi satın alma yaptığımda daha fazla ücret ödemiş olabilirim.

\section{Algılanan risk}

Çevrimiçi satın alma için ödemem gereken miktar göz önüne alındığında, çevrimiçi satın alma risklidir. Satın alınan ürünlerin kalitesindeki belirsizlik gibi olasılıklar nedeniyle internetten ürün satın almanın benim için mali kayba yol açacağını düşünüyorum.

Çevrimiçi satın alma ile ilişkili potansiyel mali harcamalar göz önüne alındığında, çevrimiçi satın alma ile ilişkili genel mali risk yüksektir.

Çevrimiçi satın almalar sonucu ortaya çıkan mali kayıp benim için önemli olacaktır.

Çevrimiçi satın alınan ürünün açıklanan işlevleri yerine getireceğinden emin değilim.

İnternetten satın alınan ürünün tatmin edici bir şekilde çalışacağına dair ciddi şüphelerim var.

Çevrimiçi satın alınan ürünün web sitesinde açılanan işlevleri yerine getirip getirmeyeceğinden emin değilim.

\section{Genel değgerlendirme}

Çevrimiçi satın almanın kesinlikle harcadığım paraya değdiğini düşünüyorum.

Fiyat göz önüne alındığında, çevrimiçi satın alınan ürünler fiyatına göre mükemmel kalitededir.

Çevrimiçi satın alırsam, önemli miktarda para biriktireceğim.

Çevrimiçi satın almanın iyi bir karar olduğuna eminim.

Çevrimiçi satın alma konusundaki tavrım olumludur.

Çevrimiçi ürünlerin fiyatları çok kabul edilebilirdir.

Tüm yönleriyle bakıldığında çevrimiçi satın almanın mükemmel bir imkan olduğunu düşünüyorum.

Çevrimiçi satın almak arzu edilir bir durumdur.

İnternetin sunduğu ürün özelliklerinin çok çekici olduğunu düşüyorum.

\section{Satın alma isteği}

Bir ürün alacak olsaydım, ürünü internetten satın alma olasılığım yüksektir.

İnternetten ürün satın almayı düşünme olasılığım yüksektir.

İnternetten satın alma olasılığım yüksektir.

\section{Tekrar satın alma niyeti}

Bir ürün satın almayı düşündüğümde ürünü internetten satın alma ihtimalim daha yüksektir.

Gelecekte internetten ürün satın alma ihtimalim yüksektir.

İnternetten alışverişi çevreme tavsiye ederim.

\section{Çalışmanın modeli ve hipotezler}

Çalışmanın modeli ve hipotezler aşağıdaki Şekil 1'de verilmiştir.

Şekil 1: Araştırma modeli ve hipotezler

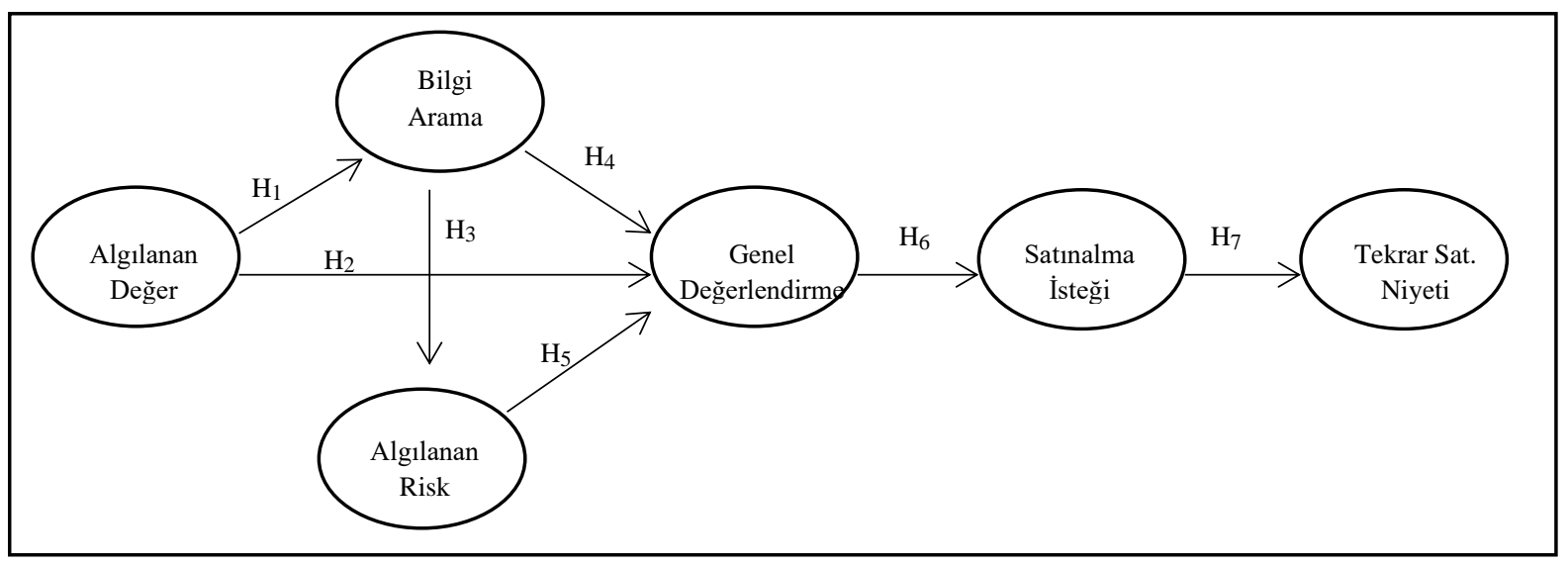




\section{Kullanılan analiz teknikleri}

Çalışmada ilk önce SPSS programı ile frekans analizi yapılmış ve katılımcıların demografik özellikleri ortaya çıkarılmıştır. Daha sonra verilerin analizinde SMARTPLS 2.0 programı kullanılarak PLS-SEM yöntemine göre Faktör Analizi ve Yol Analizi yapılmıştır. PLS-SEM yönteminde daha çok küçük örneklemler (30-100 arası) üzerinden analizin gerçekleştirilmesi önerilse de örneklemin sayısı ile ilgili kesin bir kural olmadığı da bilinmektedir (Chin ve Newsted, 1999). Ancak örneklem sayısı 250 ve üzeri olduğunda ve doğru sayıda gösterge değişken varsa, her bir yapıyı ölçmek için kullanılan diğer yapısal eşitlik modelleriyle (CB-SEM: AMOS, LISREL vb.) PLS-SEM'in sonuçları neredeyse aynı doğruluktadır (Hair vd., 2016). Dolayısıyla bu çalışmada araştırma modelinin test edilmesinde PLSSEM yöntemi kullanılmıştır.

\section{Bulgular}

\section{Demografik özellikleri ilişkin bulgular}

Çalışmada yer alan tüketicilerin betimleyici özelliklerine dair bulgular aşağıdaki Tablo 1'de verilmiştir. Tablo 1'e bakıldığında çalışmadaki tüketicilerin \%53,4'ü kadınlardan, \%46,6's1 erkeklerden oluşmaktadır. Yaş dağılımına bakıldığında en yüksek katılım \%32,2 ile 20 yaşında olanlarda, en az katılım ise \%0,8 ile 17 yaşında olan kişilerdedir. Aylık ortalama aile gelirine göre bakıldı̆̆ından en yüksek katılım \%47 ile 3000 TL ve altı geliri olanlarda, en az katılım ise \%6,4 ile 6001-7500 TL geliri olanlardadır. Meslek dağılımına bakıldığında en yüksek katılım \%60,6 ile öğrencilerde, en az katılım ise \%6,1 ile kamu sektöründe çalışan kişilerdedir. Son olarak eğitime göre bakıldığında ise en fazla katılım \%62,5 ile lisans eğitim görenlerde, en düşük katılım ise \%3 ile lisansüstü eğitim görenlerdedir.

Tablo 1: Demografik bulgular

\begin{tabular}{lccccc}
\hline Cinsiyet & Frekans & Yüzde (\%) & Yaş & Frekans & Yüzde \% \\
\hline Kadın & 141 & 53,4 & 17 & 2 & 0,8 \\
Erkek & 123 & 46,6 & 18 & 27 & 10,2 \\
Ay. Ortalama Aile Geliri & Frekans & Yüzde (\%) & 19 & 50 & 18,9 \\
3000 TL ve altı & 124 & 47,0 & 20 & 85 & 32,2 \\
$3001-4500$ & 57 & 21,6 & 21 & 66 & 25,0 \\
$4501-6000$ & 41 & 15,5 & 22 & 7 & 2,7 \\
6001-7500 & 17 & 6,4 & 23 & 10 & 3,8 \\
7501 TL ve üstü & 25 & 9,5 & 24 & 7 & 2,7 \\
Meslek/Sektör & Frekans & Yüzde (\%) & 25 & 10 & 3,8 \\
Kamu sektörü & 16 & 6,1 & Eğitim & Frekans & Yüzde (\%) \\
Özel sektör & & & Durumu & 68 & 25,8 \\
Öğrenci & 16 & 26,1 & Lise ve altı & 23 & 8,7 \\
Diğgr & 19 & 60,6 & Ön Lisans & 165 & 62,5 \\
& & 7,2 & Lisans & 8 & 3,0 \\
\hline Toplam & $\mathbf{2 6 4}$ & $\mathbf{1 0 0 , 0}$ & Toplam & $\mathbf{2 6 4}$ & $\mathbf{1 0 0}$ \\
\hline
\end{tabular}

\section{Ölçeğe ilişskin bulgular}

Çalışmada ilk olarak 32 maddeden oluşan ve araştırmacılar tarafindan Türkçe 'ye uyarlanan ölçeğin Faktör Analizi ile geçerliliğine bakılmıştır. Araştırmada kullanılan ölçeğe ait sonuçlar aşağıdaki Tablo 2'de gösterilmiştir.

Tablo 2'de verilen ölçekteki Algılanan Değer faktörünün 7. maddesinin (AD7), Algılanan Risk faktörünün 4. maddesinin (AR4) ve Genel Değerlendirme faktörünün 8. maddesinin (GD8) faktör yükleri düşük çıktığı için ölçekten çıkarılmış ve bu faktörlerin geçerlilik ve güvenilirlikleri kalan maddeler üzerinden hesaplanmıştır.

Buna göre Tablo 2'de PLS-SEM ile yapılan analiz sonucunda altı faktörün CR değerlerinin tamamının $0,8^{\prime}$ in üzerinde olduğu ve AVE değerlerinden Genel Değerlendirme faktörününki hariç tamamının da 0,5 'in üzerinde olduğu görülmektedir. Genel Değerlendirme faktörünün AVE değeri ise sınır değer olan 0,5 'e oldukça yakındır. Bununla birlikte faktörlerin tüm CR skorlarının AVE skorlarından büyük olduğu görülmektedir ve ölçeğin geçerli olduğu sonucuna varılmıştır (Hair vd., 2016). Ayrıca Cronbach Alpha ile ölçekteki faktörlerin iç tutarlılı̆ğ hesaplanmış ve buna göre Bilgi Arama ile Tekrar Satın Alma Niyeti 
faktörlerinin 0,719-0,800 arasında değerleri olduğu ve oldukça güvenilir olduğu bulunmuştur. Yine Algılanan Değer, Algılanan Risk, Genel Değerlendirme ve Satın Alma İsteği faktörlerinin ise 0,805 ve üzerinde skorları olduğu ve yüksek güvenilir olduğu görülmüştür (Tavşanc1l, 2014). Dolayısıyla araştırmacılar tarafından Türkçe'ye çevrilen ölçeğin uyum ve yakınsak geçerliliği sağladığı görülmüştür (Hair vd., 2016).

Tablo 2: Ölçeğe ilişkin bulgular

\begin{tabular}{|c|c|c|c|c|c|}
\hline Faktörler & Maddeler & Faktör Yükleri & Cronbach $\alpha$ & CR & AVE \\
\hline \multirow{7}{*}{ Algılanan Değer } & AD1 & 0,764 & \multirow{7}{*}{$\mathbf{0 , 8 0 5}$} & \multirow{7}{*}{0,862} & \multirow{8}{*}{0,516} \\
\hline & AD2 & 0,771 & & & \\
\hline & AD3 & 0,721 & & & \\
\hline & $\mathrm{AD} 4$ & 0,733 & & & \\
\hline & AD5 & 0,729 & & & \\
\hline & AD6 & 0,511 & & & \\
\hline & $A D 7$ & 0,491 & & & \\
\hline \multirow{6}{*}{ Bilgi Arama } & BA1 & 0,725 & \multirow{3}{*}{0,719} & \multirow{3}{*}{$\mathbf{0 , 8 4 2}$} & \\
\hline & BA2 & 0,862 & & & \multirow[t]{2}{*}{0,642} \\
\hline & BA3 & 0,810 & & & \\
\hline & AR1 & 0,684 & & & \multirow{7}{*}{$\mathbf{0 , 5 2 8}$} \\
\hline & AR2 & 0,676 & \multirow{6}{*}{$\mathbf{0 , 8 3 0}$} & \multirow{6}{*}{$\mathbf{0 , 8 7 0}$} & \\
\hline & AR3 & 0,725 & & & \\
\hline \multirow[t]{8}{*}{ Algılanan Risk } & $A R 4$ & 0,614 & & & \\
\hline & AR5 & 0,701 & & & \\
\hline & AR6 & 0,674 & & & \\
\hline & AR7 & 0,726 & & & \\
\hline & GD1 & 0,727 & \multirow{9}{*}{$\mathbf{0 , 8 5 5}$} & \multirow{10}{*}{$\mathbf{0 , 8 8 8}$} & \multirow{10}{*}{0,498} \\
\hline & GD2 & 0,703 & & & \\
\hline & GD3 & 0,644 & & & \\
\hline & GD4 & 0,717 & & & \\
\hline \multirow{6}{*}{ Genel Değerlendirme } & GD5 & 0,720 & & & \\
\hline & GD6 & 0,731 & & & \\
\hline & GD7 & 0,727 & & & \\
\hline & GD8 & 0,604 & & & \\
\hline & GD9 & 0,630 & & & \\
\hline & SAİ1 & 0,854 & \multirow{3}{*}{0,823} & & \\
\hline \multirow[t]{2}{*}{ Satın Alma İsteği } & SAİ2 & 0,838 & & \multirow[t]{2}{*}{0,894} & \multirow[t]{2}{*}{0,739} \\
\hline & SAİ3 & 0,885 & & & \\
\hline \multirow{3}{*}{$\begin{array}{c}\text { Tekrar Satın Alma } \\
\text { Niyeti }\end{array}$} & TSAN1 & 0,848 & \multirow{3}{*}{0,764} & \multirow{3}{*}{0,862} & \multirow{3}{*}{0,676} \\
\hline & TSAN2 & 0,790 & & & \\
\hline & TSAN3 & 0,828 & & & \\
\hline
\end{tabular}

Ölçeğin ayrışma geçerliliğine de bakılmıştır. Ayrışma geçerliliği için Fornell-Larcker kriter katsayıları hesaplanmıştır. Bulgular ise alttaki Tablo 3’te verilmiştir.

Tablo 3: Fornell ve Larcker kriter katsayıları

\begin{tabular}{ccccccc}
\hline Faktörler & $\begin{array}{c}\text { Algılanan } \\
\text { Değer }\end{array}$ & $\begin{array}{c}\text { Algılanan } \\
\text { Risk }\end{array}$ & Bilgi Arama & $\begin{array}{c}\text { Genel } \\
\text { Değerlendirme }\end{array}$ & $\begin{array}{c}\text { Satın Alma } \\
\text { İsteği }\end{array}$ & $\begin{array}{c}\text { Tekrar Satın } \\
\text { Alma Niyeti }\end{array}$ \\
\hline Algılanan Değer & $\mathbf{0 , 7 1 8 ^ { * }}$ & & & & \\
Algılanan Risk & 0,140 & $\mathbf{0 , 7 2 7 ^ { * }}$ & & & \\
Bilgi Arama & 0,604 & 0,160 & $\mathbf{0 , 8 0 2 *}$ & & \\
Genel Değerlendirme & 0,625 & 0,203 & 0,481 & $\mathbf{0 , 7 0 6 *}$ & & \\
Satın Alma İsteği & 0,491 & 0,106 & 0,386 & 0,638 & $\mathbf{0 , 8 6 0}$ & \\
Tekrar Satın Alma & 0,533 & 0,123 & 0,392 & 0,668 & 0,702 & $\mathbf{0 , 8 2 3}^{*}$ \\
$\quad$ Niyeti & & & & &
\end{tabular}

* AVE değerlerinin kareköküdür.

Fornell ve Larcker kriter katsayısında köşegen değerler faktörlerin AVE değerlerinin kareköküdür. Ve bu değerlerin, satır ve sütundaki diğer değerlerden daha büyük olması kriterdir (Fornell ve Larcker, 1981). Tablo 3'e göre bütün faktörlerin bu kriteri sağladığı anlaşılmaktadır. Başka bir ifadeyle ölçek 
ayrışma geçerliliğini de sağlamaktadır. Ölçeğin faktör yapısı doğrulandıktan ve yapısal uyumu saptandıktan sonra modelin Yol Analizi ile test edilmesine geçilmiştir.

\section{Yol analizine ilişkin bulgular}

Çalışmanın modeline ait Yol Diyagramı aşağıdaki Şekil 1'de verilmiştir.

Şekil 2: Araştırma modeli

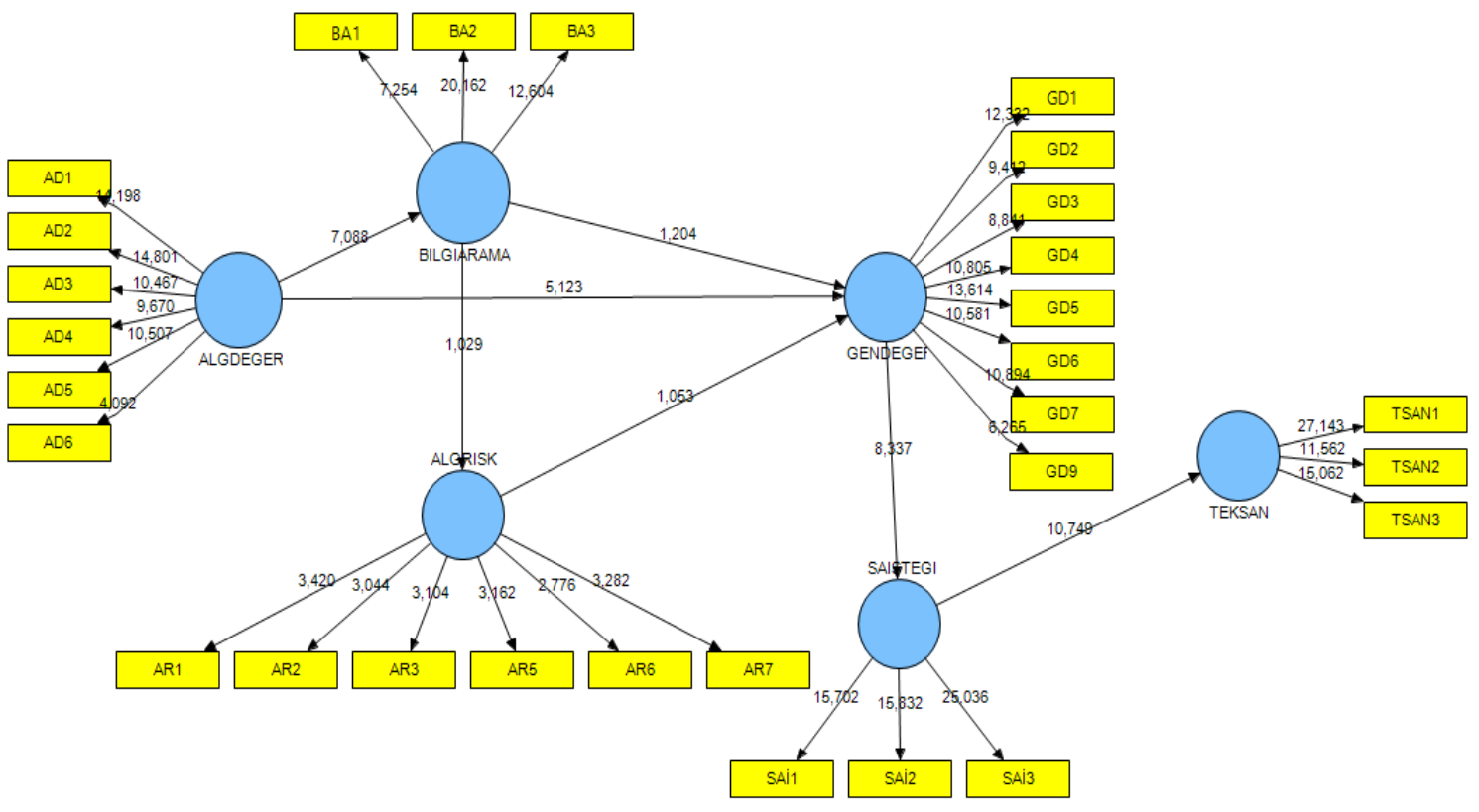

Şekil 2'deki modelde yer alan değişkenlerden Algılanan Değer, Bilgi Arama ve Algılanan Risk bağımsız değişkenleri; Genel Değerlendirme ve Satın Alma İsteği aracı değişkenleri ve Tekrar Satın Alma Niyeti ise bağımlı değişkeni ifade etmektedir. PLS-SEM' de 5000 birimlik bootstrap uygulanarak modeldeki yolların anlamlılığı test edilmiştir. Elde edilen bulgular aşağıdaki Tablo 4'deki gibidir.

Tablo 4: Yol katsayılarına ait bulgular

\begin{tabular}{lccccc}
\hline \multicolumn{1}{c}{ Yollar } & $\begin{array}{c}\text { Araştırma } \\
\text { Orrneklemi }\end{array}$ & $\begin{array}{c}\text { Örneklem } \\
\text { Ortalaması }\end{array}$ & $\begin{array}{c}\text { Standart } \\
\text { Hata }\end{array}$ & T İstatistiği & $\begin{array}{c}\text { Hipotez } \\
\text { Durumu }\end{array}$ \\
\hline H1:Algılanan Değer -> Bilgi Arama & 0,604385 & 0,612158 & 0,085270 & 7,087925 & Kabul \\
H2:Algılanan Değer -> Genel Değerlendirme & 0,520207 & 0,529076 & 0,101538 & 5,123264 & Kabul \\
H3:Bilgi Arama -> Algılanan Risk & 0,159429 & 0,201078 & 0,154960 & $\mathbf{1 , 0 2 8 8 3 9}$ & Ret \\
H4:Bilgi Arama -> Genel Değerlendirme & 0,148775 & 0,128232 & 0,123565 & $\mathbf{1 , 2 0 4 0 2 6}$ & Ret \\
H5:Algılanan Risk -> Genel Değerlendirme & 0,106400 & 0,129471 & 0,101012 & $\mathbf{1 , 0 5 3 3 3 4}$ & Ret \\
H6:Genel Değerlendirme -> Satın Alma İsteği & 0,637528 & 0,646681 & 0,076471 & 8,336844 & Kabul \\
H7:Satın Alma İsteği -> Tekrar Satın Alma Niyeti & 0,701516 & 0,710449 & 0,065262 & $\mathbf{1 0 , 7 4 9 2 2 9}$ & Kabul \\
\hline
\end{tabular}

PLS-SEM'de yollara (regresyon ilişkilerine) ait t değerlerinin 1,96'dan büyük olması yol katsayılarının anlamlı olduğunu gösterir. Tablo 4'e göre Algılanan Değer Bilgi Aramayı pozitif ve anlamlı olarak yaklaş1k \%60 oranında etkilemektedir ve $\mathrm{H}_{1}$ hipotezi kabul edilmiştir. Yine Algılanan Değer, Genel Değerlendirmeyi pozitif ve anlamlı olarak yaklaşı $\% 52$ oranında etkilemektedir ve $\mathrm{H}_{2}$ hipotezi kabul edilmiştir. Bilgi Aramanın ise Algılanan Risk ve Genel Değerlendirme değişkenleri üzerinde herhangi anlamlı bir etkisi yoktur ve $\mathrm{H}_{3}$ ile $\mathrm{H}_{4}$ hipotezleri reddedilmiştir. Yine Algılanan Riskin de Genel Değerlendirme üzerinde anlaml bir etkisi yoktur ve $\mathrm{H}_{5}$ hipotezi de reddedilmiştir. Genel Değerlendirmenin ise Satın alma İsteği üzerinde pozitif etkisi vardır ve yaklaşık \%64 oranında 
etkilemektedir. Böylece $\mathrm{H}_{6}$ hipotezi kabul edilmiştir. Son olarak Satın Alma İsteğinin de Tekrar Satın Alma Niyeti üzerinde pozitif etkisi vardır ve yaklaşık olarak \%70 oranında etkilemektedir. Buna göre $\mathrm{H}_{7}$ hipotezi de kabul edilmiştir.

SMARTPLS programı analiz sonucunda belirlilik katsayılarını da vermektedir. Buna göre etki büyüklüğü sonuçları Tablo 5'te gösterilmiştir.

Tablo 5: Belirlilik katsayıları

\begin{tabular}{lc}
\hline Bağımlı Değişkenler & $\mathbf{R}^{\mathbf{2}}$ \\
\hline Bilgi Arama & 0,365 \\
Genel Değerlendirme & 0,418 \\
Satın Alma İsteği & 0,406 \\
Tekrar Satın Alma Niyeti & 0,492 \\
\hline
\end{tabular}

Tablo 5'e göre Alg1lanan Değer, Bilgi Arama ve Algılanan Risk değişkenleri hep birlikte Genel Değerlendirmeyi yaklaşık olarak \%42 oranında etkilemektedirler. Yine Algılanan Değer, Bilgi Arama, Algılanan Risk ve Genel Değerlendirme değişkenleri hep birlikte Satın Alma İsteğini yaklaşı olarak \%41 oranında etkilemektedirler. Son olarak Algılanan Değer, Bilgi Arama, Algılanan Risk, Genel Değerlendirme ve Satın Alma İsteği değişkenleri ise hep birlikte Tekrar Satın Alma Niyetini yaklaşık olarak \%49 oranında etkilemektedirler. Başka bir ifadeyle Z kuşağından tüketicilerin dijital pazarlardaki satın alma karar süreçlerinin yaklaşık \%49'luk kısmının bu değişkenler tarafından açıklandığı söylenebilir.

SMARTPLS programında modelin yapısal uyumu için $Q^{2}$ (Kesitirimsel Uygunluk) değeri kullanılır. Buna göre araştırma modeline ait $\mathrm{Q}^{2}$ değerleri aşağıdaki Tablo 6' da verilmiştir.

Tablo 6: $Q^{2}$ Değerleri

\begin{tabular}{cccc}
\hline Total & SSO & SSE & $\mathbf{Q}^{\mathbf{2}}=\mathbf{1 - S S E} /$ SSO \\
\hline Algılanan Değer & 1584,0000 & 1055,9421 & $\mathbf{0 , 3 3 3 4}$ \\
Algılanan Risk & 1848,0000 & 1320,2291 & $\mathbf{0 , 2 8 5 6}$ \\
Bilgi Arama & 792,0000 & 559,6112 & $\mathbf{0 , 2 9 3 4}$ \\
Genel Değerlendirme & 2112,0000 & 1375,0814 & $\mathbf{0 , 3 4 8 9}$ \\
Satın Alma İsteği & 792,0000 & 429,2452 & $\mathbf{0 , 4 5 8 0}$ \\
Tekrar Satın Alma Niyeti & 792,0000 & 515,9196 & $\mathbf{0 , 3 4 8 6}$ \\
\hline
\end{tabular}

$\mathrm{Q}^{2}$ kestirimsel uygunluk değeri modelin ve ona ait parametre tahminleri tarafindan gözlemlenen değerlerin ne ölçüde iyi yeniden yapılandırıldığını gösteren bir kriterdir (Chin, 1998). $\mathrm{Q}^{2}>0$ modelin kestirimsel uygunluğu sağladığını, $\mathrm{Q}^{2}<0$ ise sağlamadığını gösterir. Yukarıdaki Tablo 6'ya göre modeldeki tüm değişkenlerin $\mathrm{Q}^{2}$ değeri pozitiftir ve dolayısıyla model yapısal olarak uyumludur.

\section{Sonuç ve öneriler}

Teknolojinin gelişimi ve internet kullanımının artması, tüketici davranışlarını ve işletmelerin iş yapma şekillerini değiştirmiştir. Dijitalleşme, düşük maliyetler, marka bilinirliği ve satışların artması gibi unsurlar işletmelere önemli firsatlar sunmaktadır (Dwivedi vd., 2021). İnternet, dünya çapında iletişim ve iş için vazgeçilmez bir araç haline geldiğinden çevrimiçi alışveriş de tüketiciler için vazgeçilmez olmuştur. Bu kapsamda dijital pazarlarda $\mathrm{Z}$ kuşağında yer alan tüketicilerin satın alma karar sürecini incelemek amacıyla yapılan bu çalışmada elde edilen bulgular şu şekildedir.

Araştırmacılar tarafından geliştirilen model ilk olarak PLS-SEM ile Faktör Analizine tabi tutulmuş ve Türkçeye çevrilen ölçeğin uyum, yakınsak ve ayrışma geçerliliği ile iç tutarlılığına bakılmıştır. Buna göre ölçekte yer alan Algılanan Değer, Bilgi Arama, Algılanan Risk, Genel Değerlendirme, Satın Alma İsteği ve Tekrar Satın Alma Niyeti faktörlerinin hepsinin CR, AVE değerleri istenen aralıkta olduğundan 
uyum ve yakınsak geçerliliği sağladığı görülmüştür. Ayrışma Geçerliliği için Fornell ve Lacker kriter katsayılarına bakılmış ve tüm faktörlerin ayrışma geçerliliğini de sağladığı tespit edilmiştir. İç tutarlılık için Cronbach Alpha katsayılarına bakılmış Bilgi Arama ile Tekrar Satın Alma Niyeti faktörlerinin 0,719-0,800 arasında değerleri olduğu ve oldukça güvenilir olduğu bulunmuştur. Yine Algılanan Değer, Algılanan Risk, Genel Değerlendirme ve Satın Alma İsteği faktörlerinin ise 0,805 ve üzerinde skorları olduğu ve yüksek güvenilir olduğu görülmüştür.

Çalışmanın ikinci aşamasında model Yol Analizi ile test edilmiş ve ilişkiler ortaya konularak hipotezlerin geçerliliğine bakılmıştır. Buna göre "Algılanan Değer" "Bilgi Aramayı" pozitif olarak yaklaşı $\% 60$ oranında etkilemektedir ve $\mathrm{H}_{1}$ hipotezi kabul edilmiştir. Yine "Algılanan Değer", "Genel Değerlendirmeyi" pozitif olarak yaklaşık \%52 oranında etkilemektedir ve $\mathrm{H}_{2}$ hipotezi kabul edilmiştir. Bu bulguları destekleyici çalışmalar literatürde mevcuttur. Khatibi vd. (2006) ve Harn vd. (2006) çalışmalarında algılanan değerin bilgi aramayı pozitif bir şekilde etkilediğini; Teo ve Yeong (2003) ise yaptıkları çalışmada algılanan değer ile genel değerlendirme arasında pozitif bir ilişki olduğunu tespit etmişlerdir. Mevcut çalışmada, "Genel Değerlendirmenin" "Satın Alma İsteği”" üzerinde pozitif bir etkisi olduğu ve yaklaşık \%64 oranında etkilediği tespit edilmiş̧tir. Böylece $\mathrm{H}_{6}$ hipotezi kabul edilmiştir. "Satın Alma İsteğinin" ise "Tekrar Satın Alma Niyeti” üzerinde pozitif bir etkisi olduğu ve yaklaşı olarak $\% 70$ oranında etkilediği sonucuna ulaşılmıştır. Buna göre $\mathrm{H}_{7}$ hipotezi de kabul edilmiştir. Dolayısıyla kurulan hipotezlerden $\mathrm{H}_{1}, \mathrm{H}_{2}, \mathrm{H}_{6}$ ve $\mathrm{H}_{7}$ kabul edilmiştir. Cronin vd. (2000) çalışmalarında, algılanan değer ve müşteri memnuniyetinin tekrar satın alma niyetine etkisinin olduğunu; Petrick ve Backman (2002) ise, algılanan değer ve müşteri memnuniyetinin tekrar satın alma niyetinin belirleyicisi olduğunu belirtmişlerdir.

Ayrıca çalışmada; "Bilgi Aramanın" "Algılanan Risk" üzerinde bir etkisi tespit edilememiş ve $\mathrm{H}_{3}$ hipotezi ret edilmiştir. Teo ve Young (2003) tarafından yapılan çalışmada da benzer bir sonuç elde edilmiş ve bilgi aramanın algılanan risk üzerinde bir etkisinin olmadığı belirtilmiştir. Aynı zamanda "Bilgi Aramanın" "Genel Değerlendirme" üzerinde de bir etkisi bulunamamış ve $\mathrm{H}_{4}$ hipotezi de ret edilmiştir. Bu bulgunun aksine Teo ve Young (2003) ve Chaturvedi vd. (2016) tarafindan yapılan çalışmalarda bilgi aramanın genel değerlendirme üzerinde pozitif etkisi bulunmuştur. Son olarak; "Algılanan Riskin" "Genel Değerlendirme" üzerinde negatif bir etkiye sahip olduğu yönündeki hipotezde ret edilmiştir $\left(\mathrm{H}_{5}\right)$. Bu sonucun tersine Wood ve Scheer (1996), Teo ve Young (2003) çalışmalarında algılanan riskin genel değerlendirmeyi negatif etkilediğini tespit etmişlerdir.

İnternet kullanıcılarının sayısının giderek artmasından dolayı tüketicilerin karar alma mekanizmaları sürekli değişmektedir. Bu nedenle özellikle internet üzerinden satış yapan işletmelerin bu değişiklikleri dikkate alarak pazarlama faaliyetlerini buna göre uyarlamaları gerekmektedir. İşletmeler sanal gerçeklik, artırılmış gerçeklik, yapay zeka gibi uygulamaları kendi faaliyetlerine uyarlamalıdırlar. İnternet ve bilgi teknolojilerini etkin olarak kullanan işletmeler rekabet avantajı, verimlilik artışı, etkinlik, kar artışı vb. avantajlar elde edeceklerdir (Karaca, 2012). Ayrıca akıllı telefonlar, sosyal medya platformları ve elektronik ağızdan ağıza iletişim gibi farklı mecralar aracılığıyla internet üzerinden teknoloji ve bilginin yoğun bir şekilde yayılması nedeniyle dünya çapında iletişimde büyük gelişmeler yaşanmaktadır. Bu teknolojik gelişmeler dünyayı küresel bir köy haline getirmiştir. Tüketiciler sürekli olarak ürünler ile ilgili bilgileri ve hizmetleri aramak için dijital iletişim kanallarını kullandıkları için internet günlük yaşamın bir parçası haline gelmiştir. Özellikle işletmelerin dijital ortamdan ürünlerine ilişkin sundukları bilgilerin güvenilir olması insanların algıladıkları riski azaltacak ve tüketiciler bu bilgilere güvenerek satın alma kararını daha rahat bir şekilde vereceklerdir. Bu nedenle işletmelerin dijital ortamlarda doğru bilgi vermesi tüketicinin güvenini sağlaması çok önemlidir.

Bu çalışmanın en önemli kısıtı çalışmanın sadece Z kuşağı tüketicilerine yapılmasıdır. İkinci olarak kısa bir zaman dilimi ve online olarak verilerin toplanmasından dolayı da elde edilen sonuçlar tüm evrene genellenememektedir. Bu nedenlerden dolayı araştırmanın daha uzun bir zaman dilimi ve diğer kuşaklarda yer alan tüketicileri de kapsayacak şekilde yapılması sonuçların genellenebilmesi açısından önemlidir. Ayrıca dijitalleşmenin tüm sektörlere etkisi göz önüne alındığında dijitalleşme ile ilgili farklı disiplinlerdeki çalışmaların sayısı daha fazla artırılması gerekmektedir. 


\section{Kaynakça}

Agarwal, S., ve Teas, R. K. (2002). Cross-national applicability of a perceived quality model. Journal of Product \& Brand Management, 11(4), 213- 236.

Chaturvedi, S., Gupta, S. ve Singh Hada, S. (2016). Perceived risk, trust and information seeking behavior as antecedents of online apparel buying behavior in India: an exploratory study in context of rajasthan. International Review of Management and Marketing, 6(4), 935-943.

Chin, W. W. (1998). The partial least squares approach to structural equation modeling. in: G. A. Marcoulides (Ed.), Modern Methods for Business Research (pp. 295-358).

Chin, W. W. ve Newsted, P. R. (1999). Structural Equation modeling analysis with small samples using partial least squares. R. Hoyle (Ed.). Statistical strategies for small sample research içinde (pp.307-341). Thousand Oaks, Sage Publications.

Cronin, J.J., Brady, M.K. ve Hult, G.T. (2000) Assessing the effects of quality, value and customer satisfaction on consumer behavioral intentions in service environments. Journal of Retailing, 76, 193-218.

Dwivedi, Y. K., Ismagilova, E., Hughes, D.L., Carlson, J., Filieri, R., Jacobson, J. vd. (2021). Setting the future of digital and social media marketing research: Perspectives and research propositions. International Journal of Information Management, 59, 1-37.

Eeuwen, M. V. (2017). Mobile conversational commerce: messenger chatbots as the next interface between businesses and consumers [Thesis], University Of Twente.

Eng, T.Y. ve Kim, E.J. (2006), An examination of the antecedents of e-customer loyalty in a confucian culture: the case of South Korea. The Service Industries Journal, 26(4), 437-58.

Eszes I. (2011). Digitális gazdaságtan [Digital economics]. Budapest, Nemzeti Tankönykiadó. F1kusz 2016 At: Óbuda University, Budapest, Hungary.

Fornell, C. ve Larcker, D.F. (1981). Evaluating structural equation models with unobservable va-riables and measurement error. Journal of Marketing Research, 18, 39-50.

Goldsmith, R. E. ve Horowitz, D. (2006). Measuring motivations for online opinion seeking. Journal of Interactive Advertising, 6(2), 1-16.

Hair, J.F., Hult, G.T.M., Ringle, C.M. ve Sarstedt, M. (2016). A primer on partial least squares structural equation modeling (PLS-SEM). Sage Publications.

Harn, A.C.P., Khatibi, A. ve Ismail, H.B. (2006). E-commerce: A study on online shopping in Malaysia. Journal of Social Sciences, 13(3), 231-242.

Hidvégi, A. ve Kelemen-Erdős A. (2016). Assessing the online purchasing decisions of generation Z. R. Z. Reicher (Ed.). Proceedings of FIKUSZ 2016 içinde (pp.173-181). Óbuda University, Budapest, Hungary.

Jobber, D. ve Ellis-Chadwick, F. (2013). Principles and practice of marketing (7th ed.). McGraw-Hill Education.

Kahawandala, N. ve Peter, S. (2020). Factors affecting purchasing behaviour of generation Z, IEOM Society International, Proceedings of the International Conference on Industrial Engineering and Operations Management Dubai, UAE, March 10-12, 1153-1162.

Karaca, Ş. (2012). İnternette pazarlama ve ürün karar stratejileri. Çukurova Üniversitesi İ̈BF Dergisi, 16(1), 37-51.

Khatibi, A., Haque, A. ve Karim, K. (2006). E-commerce: A study on internet shopping in Malaysia. Journal of Applied Sciences, 6(3), 696-705.

Kutasi, N. (2013). Conquerors of the Cyber Space-the Z generation. Társadalomkutatás, 31(2), 195202.

Mandilasa, A., Karasavvogloua, A., Nikolaidisa, M. ve Tsourgiannisa, L. (2013). Predicting consumer's perceptions in on-line shopping. Procedia Technology, 8, 435-444.

Marmorstein. H., Grewal, D. ve Fishe, R.P.H. (1992). The value of time spent in price comparison shopping: survey and experimental evidence. Journal of Consumer Research,19, 52-61.

McCrindle, M. (2014). The ABC of XYZ:Understanding the global generations. Sydney UNSW Press.

McCrindle, M. ve Fell, A. (2019). Understanding generation Z: Recruiting, training and leading the next generation. McCrindle Research Pty Ltd.

Mohseni, S. ve Sreenivasan, J. (2014). The impact of user characteristics in online purchase intention in tourism industry. Reef Resources Assessment and Management Technical Paper, 40(1), 399-404. 
Oliver, H., Volschenk, J. ve Smit, E. (2011). Residential consumers in the Cape Peninsula's willingness to pay for Premium-priced green electricity. Energ Policy, 39, 544.550.

Omar, A. M. ve Atteya, N. (2020). The impact of digital marketing on consumer buying decision process in the Egyptian market. International Journal of Business and Management, 15(7), 120-132.

Omarl1, S. ve Parılt1, N. (2018). Effects of electronic marketing on purchasing behaviors of consumers, application on students of university in Turkey. Journal of Anatolian Cultural Research, 1(3), 91109.

Paakkari, A. (2016). Customer journey of generation Z in fashion purchases. Lahti University of Applied Sciences Ltd Degree Programme in International Business.

Palfrey, J. ve Gasser, U. (2008). Born digital. Basic books. New York.

Palos-Sanchez, P. ve Saura, J. R. (2018). The E_ect of Internet Searches on A_orestation: The case of a green search engine. Forests, 9, 51.

Pineiro-Otero, T. ve Martínez-Rolan, X. (2016). Understanding digital marketing-basics and actions içinde C. Machado ve J. Paulo Dawim (Ed.). MBA: Theory and application of business and management principles içinde (pp.37-74). Springer.

Ponomarenko, A. (2018). B2B digital marketing plan for attracting new international customers and building brand awareness globally. School of Business Degree Programme in International Business.

Priporas, C.V., Stylos, N. ve Fotiadis, A.K. (2017). Generation Z consumers' expectations of interactions in smart retailing: A future agenda. Computers in Human Behavior,77, 374-381.

Punj, G. Ve Moore, R. (2009). Information search and consideration set formation in a web-based store environment. Journal of Business Research, 62(6), 644-650.

Rachinger, M., Rauter, R., Müller, C., Vorraber, W. ve Schirgi, E. (2019). Digitalization and its influence on business model innovation. Journal of Manufacturing Technology Management, 30(8), 1143-1160.

Saydan, R. (2008). Tüketicilerin online alışverişe yönelik risk ve fayda algılamaları: geleneksel ve online tüketicilerin karşılaştırılması. Elektronik Sosyal Bilimler Dergisi, 7(23), 386-402.

Shergill, G.S. ve Chen, Z. (2005). WEB-based shopping: Consumers'attitudes towards online shopping in New Zealand. Journal of Electronic Commerce Research, 6(2), 79-94.

Suki, N.M.ve Suki, N.M. (2007). Online buying innovativeness: effects of perceived value, perceived risk and perceived enjoyment. International Journal of Business and Society, 8(2), 81-93.

Tavşancıl, E. (2002). Tutumların ölçülmesi ve spss ile veri analizi. Nobel Yayınc1lık.

Teo, T. S.H. ve Yeong, Y. D. (2003). Assessing the consumer decision process in the digital marketplace. Omega, 31, 349-363.

Williams, K. C. ve Page, R. A. (2011). Marketing to the generations. Journal of Behavioral Studies in Business, 3(1), 1-17.

Wood, C. M. ve Scheer, L. K. (1996). Incorporating perceived risk into models of consumer deal assessment and purchase intent. Advances in Consumer Research, 23, 399-404.

$\mathrm{Wu}$, S. (2002). Internet marketing involvement and consumer behaviour. Asia Pasific Journal of Marketing and Logistics, 14(4), 411.

\section{Etik kurul onayı}

Sivas Cumhuriyet Üniversitesi Sosyal Bilimler Etik Kurulu tarafından 07/06/2021 tarih ve 050.06.0445675 sayılı etik kurul onayı alınmıştır.

\section{Araştırmacıların katkı oranı beyanı}

Yazarlar çalışmaya eşit oranda katkı sağlamıştır.

Çıkar çatışması beyanı

Bu çalışmada herhangi bir potansiyel çıkar çatışması bulunmamaktadır. 